INTERNATIONAL DESIGN CONFERENCE - DESIGN 2018

https://doi.org/10.21278/idc.2018.0169

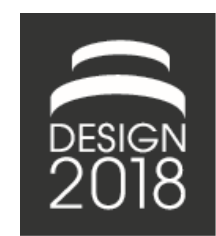

\title{
HOW TO DESIGN METHODS FOR APPLICATION - EMPIRICAL INSIGHTS FROM INDUSTRY
}

\author{
M. R. Guertler
}

\begin{abstract}
Methods support designers in systematically developing new or improving products and processes. Despite their benefits, the use of methods in industry is still limited. Methods are often perceived as too abstract and not suitable by industry users. Research has tended to focus on the selection and application of methods. This paper proposes to extend the scope and include the design of methods themselves. Based on literature and empirical insights from research projects in industry, it derives a first set of requirements for designing new methods and increasing their usability and acceptance.
\end{abstract}

Keywords: design methods, design methodology, requirements management, industry application

\section{Introduction}

This research addresses the successful application of design and innovation methods / tools in industry through a focus extension from the selection and implementation of methods to their very design itself. Companies are confronted with various challenges, such as fastened innovation cycles, dynamically changing customer needs and limited resources. To increase their performance and stay competitive, companies continuously need innovative products (Gronum et al., 2012; Feller et al., 2013). This usually requires the collaboration of different disciplines and departments as well as fastened innovation cycles (Gericke et al., 2013). As a consequence, firms face challenges, such as increased product complexity, high time pressure (Graner, 2013) and varying levels of experience and skills of particular designers (Grabowski and Geiger, 1997; Braun, 2005).

In the context of innovation management and engineering design, design methods and tools support a purposeful and successful development of products even under time pressure and for complex systems (Graner, 2013). Methods also help to overcome social and psychological barriers, such as fixation on established solutions, barriers of thinking and lack of communication between different disciplines. In line with Albers and Schweinberger (2001), Graner (2013) empirically showed that the application of methods supports the general success of product development activities and strengthens the innovativeness of companies. Similar to recipes, they provide guidance to unexperienced users as well as inspiration for alternative procedures to experienced users. They can and need to be adapted to the specific problem and application context (see Section 3.1). Their inherent procedure of necessary actions ensures a systematic development of particular results (cf. Birkhofer et al., 2002; Gericke et al., 2017), that are therefore no longer solely based on the individual experience and competences of users or even accidental products (Braun, 2005).

Despite these benefits, design and innovation methods are not comprehensively applied in industry (Tomiyama et al., 2009; Albers et al., 2012; Lindemann, 2016; Gericke et al., 2017). Although an increasing number of methods have become compulsory due to quality management and certification 
reasons, there is a general scepticism and lack of acceptance of methods in companies (Lindemann, 2016). Potential reasons are a lack of understanding the benefits and efforts as well as an insufficient adaptability to the application context (Eckert and Clarkson, 2005; Albers et al., 2012). In line with the previous authors, Braun (2005) states that methods are often considered as too abstract for industrial use, particularly new methods coming from academia. Already Lopez-Mesa et al. (2004) stated the issue of academia developing numerous design methods that often do not have any impact in industry.

To date, research has usually considered this issue from a method communication, selection, training and implementation perspective. However, the design of methods itself has rarely been in the focus of academia. Researchers and sometimes companies tend to develop new methods to solve specific issues in companies. In this respect, researchers and practitioners repeatedly face similar challenges and barriers as well as resulting mistakes, such as non-intuitive or inflexible designs or insufficient costbenefit ratios of their application (cf. Albers et al., 2012). In particular, data collection mechanisms of methods seem to be a key success factor and challenge (Guertler et al., 2016). Along with unnecessary project delays, insufficient method designs can risk their acceptance in the cooperating company. In this respect, academia hitherto analysed primarily barriers of method application (Badke-Schaub et al., 2011; Albers et al., 2012). Although they already comprise implicit success factors, explicit requirements of method design or even checklists are lacking or rather limited. Still some explicit requirements exist but are scattered over different publications. This advice often states relevant aspects such as adaptability but only on an abstract level without providing operative details.

Thus, there is a need for a systematic analysis of success factors and barriers of designing methods and tools. This provides other researchers with a better understanding of methods application in industry or practice in general. In addition, consolidating them in a requirement and/or checklist provides other researchers with operational support when developing new design methods. This can help to reduce the risk of typical greenhorn mistakes which might jeopardise acceptance and application of methods in industry. The underlying research questions are: Which general requirements from industry concerning method design do exist? Which method-focused success factors and barriers influence the success of method application in industry?

To provide an initial answer to these questions, this paper first analyses insights and derives requirements from literature in Section 3. These are evaluated and enhanced through empirical insights from different industry research projects in Section 4. The findings from literature and empirical projects are consolidated in an initial requirement list of designing methods and tools. Section 5 provides a summary of this paper, its contribution and limitations as well as necessary following research steps.

\subsection{Research design}

In the first step, a literature analysis is conducted concerning existing indications of developing methods for industry. In general, these show a primary focus on barriers of method application. Therefore, these barriers are analysed concerning inherent requirements and rules of method design. In addition, the barrier framework of Albers et al. (2012) is adapted and extended by a new dimension focussing on the data collection mechanisms of design methods (Figure 1), based on insights from Guertler et al. (2016). The derived method requirement framework serves as conceptual basis for the subsequent empirical requirement analysis. This second step comprises the empirical analysis of method design in different research projects in industry. These projects focused the development of new methods for specific industry problems and evaluated their resulting applicability and outcomes. To gain deep insights in the industry perception of these methods and to build a broad understanding of different method contexts, the selection criteria of these projects are: (1) a close cooperation between university and company when developing and evaluating new design methods/tools, (2) a variety of different addressed design problems to find initial indications for generalisability of findings.

The projects themselves are based on an action research approach. Following an analysis of the specific industry engineering design problem and analysis of the particular academic state of the art, a requirement analysis concerning the methodical support is conducted with the industry partners. Based on this, new methods and tools are developed for the problem by adapting and combining existing theory and methods from academia as well as newly designed methods. To evaluate their applicability and 
performance, industry partners are observed in using them, followed by a discussion of their experience. Similar to Gericke et al. (2016), the success evaluation of the methods is based on a subjective assessment of industry partners as well as an assessment if the achieved methods' outcomes in relation to the specific project goals. This allows to identify different enablers and barriers of methods application. Reflecting these findings onto the requirement framework (Figure 1) allows to derive requirements of designing new methods/tools (details about reflective questions see Section 4.2). Subsequently, requirements from literature and industry projects are consolidated and grouped. Structuring the resulting requirement framework as requirement list supports its utilisation as checklist by other researchers for designing new methods.

\section{State of the art: Design methods and their successful application}

After defining the term "method" and related terms, this section provides an overview of relevant research concerning the application of methods and key barriers in industry. They are analysed concerning implicit requirements of method design.

\subsection{Definition of methods, methodologies and tools}

Methods (also "design method" or "innovation method") support engineering design and innovation management, for instance, in the context of process management and product engineering models. Methods represent a systematic and rule-based procedure that comprises several steps to achieve specific objectives. They provide guidance for users by their prescriptive and operative character and can - but also need - to be adapted to the specific problem and application context (Ulrich and Eppinger, 2008; Lindemann, 2009; Ehrlenspiel and Meerkamm, 2013). Albers et al. (2014) state five categories of methods for product development: (1) analysis methods, (2) creativity methods, (3) evaluation/decision methods, (4) planning and control methods, and (5) methods for rework and learning.

Closely linked are method tools as technical implementations of methods (Lindemann, 2009; Gericke et al., 2017). They facilitate the application and the usability of methods and support their effectiveness and efficiency (Kirschner, 2012). They can range from simple paper-based tools up to complex software systems.

Methodologies are consistent combinations of different single methods (Lindemann, 2009; Kirschner, 2012). Pahl et al. (2007) define a design methodology as "concrete course of action for the design of technical systems (...). It includes plans of action that link working steps and design phases according to content and organisation".

In the context of this paper, method users can be anyone in industry or academia who applies a particular method to solve a specific design or innovation management task.

\subsection{Success factors and barriers of method application}

Within his empirical study analysing the benefits of methods in industry, Graner (2013) identifies general, required success factors of method application, such as the existence of a formal product development process, top-management support, department-spanning collaboration and innovativeness of products. From a method design perspective, Braun (2005) provides general recommendations for developing methodical support in SMEs. He differentiates different levels of support and required expertise of method users. For instance, while inexperienced users need pre-configured methodical guidelines, more generic guidelines are more suitable for experienced users. On a method level, he addresses the deployment and selection of methods but provides only limited advice concerning the designing of methods.

\subsubsection{Barriers of method application in industry}

Other researchers focus on barriers of method application. Albers et al. $(2012,2014)$ analyse the reasons of insufficient systems engineering method application and exploitation of related benefits in companies. General issues are a lack of expertise of potential users concerning the utilisation of methods and the large variety of available methods, which can easily overwhelm users. In respect of designing 
methods, they find the following common shortcomings, which are in line with other authors, such as (Eckert and Clarkson, 2005; Hutterer, 2005; Gericke et al., 2013, 2017):

- Insufficient consideration of individual needs and capabilities of method users,

- Insufficient consideration of individual ways of working and thinking,

- Difficulties to show the benefits of methods,

- Lack of integration of methods into company processes,

- Difficulties to learn along with their often too abstract presentation, and

- Lack of adaptability or of according support to adapt methods.

Badke-Schaub et al. (2011) present a framework that structures barriers of method application in three categories, which are in line with Braun (2005): (1) performance, which addressed the perceived performance of methods; (2) presentation, in terms of advertisement as well as representation; and (3) process, in terms of flexibility and adaptability of the inherent method steps. Albers et al. (2012) extend this framework by a second dimension: the method user. They differentiate individuals who operatively use the method, and organisations, which introduce methods in their processes (Figure 1). A differentiation in method beginners, experienced users and experts (Braun, 2005; cf. Bavendiek et al., 2016) is not considered.

Another critical aspect of a successful method application are data collection mechanisms since they affect, for instance, the effort and the quality of the collected and processed data ("nonsense in, nonsense out"), and the overall cost-benefit ratio of a method (Guertler et al., 2016). Thus, this research enhances the acceptance barrier framework of Albers et al. (2012) by an additional data collection dimension, as illustrated in Figure 1.

\begin{tabular}{|c|c|c|c|c|}
\hline & Performance & Presentation & Process & Data collection \\
\hline Individual & $\begin{array}{c}\text { perceived } \\
\text { performance }\end{array}$ & $\begin{array}{l}\text { intuitively } \\
\text { applicable }\end{array}$ & $\begin{array}{l}\text { flexible and } \\
\text { adaptable }\end{array}$ & $\begin{array}{l}\text { comprehensible } \\
\text { and reproducible }\end{array}$ \\
\hline Organisational & cost-benefit ratio & $\begin{array}{l}\text { teachable and } \\
\text { learnable }\end{array}$ & $\begin{array}{c}\text { reusable and } \\
\text { enhanceable }\end{array}$ & $\begin{array}{l}\text { targeted and } \\
\text { secure }\end{array}$ \\
\hline
\end{tabular}

Figure 1. Requirement framework of methods/tools (Albers et al., 2012)

\subsubsection{Initial requirements for methods design}

The previous literature comprises various implicit requirements of method design. In some cases, requirements are stated more explicitly such as Gericke et al. (2013), who state the need for adaptability and analyse corresponding influencing factors. Braun (2005) also states the need of flexibility of methods and provides an overview of different ways to implement it such as elementary methods which represent building blocks and can be situation-specifically composed. Similarly, LopezMesa et al. (2004) consider methods as "networks of sub-methods" and state rough design rules as requirements, i.e. it is necessary to clarify the purpose ("what for"), the application scenario ("when") and the application procedure ("how") of a method. Concerning its purpose, Braun and Lindemann (2003) propose to link methods to corresponding product development phases or phases of engineering procedure models such as VDI 2221. More specific requirements of method design are presented by Albers and Schweinberger (2001), e.g.:

- Ensure a simple and comprehensible method description (reduced learning \& application effort)

- Limit theoretical background information to a minimum,

- Consider a potential tool implementation from the beginning,

- Ensure adaptability (e.g. method toolboxes instead of a universal method), and

- State benefits of a method transparently.

Still, the number of requirements is limited, and they are usually rather abstract. There is the need of a more detailed industry-based requirement analysis that considers needs stated directly by companies. 


\section{Empirical requirement analysis of designing methods and tools}

The following section provides an overview of the analysed research projects in industry, which represent the empirical basis of this paper. The method requirement framework (Figure 1) serves as basis to structure requirements, which were explicitly stated by the specific industry partners, as well as originally tacit requirements, which are derived from empirical findings and observations in the projects.

\subsection{Empirical basis: Project description}

Concerning the selection of case studies, the focus was on different contexts, scopes and goals to ensure a broad view on requirements of method design in industry. The case studies can be differentiated in three groups of projects: (1) developing a methodical guideline (methodology) for planning Open Innovation (OI) projects in cooperation with three family firms, (2) evaluating the previous planning methodology in cooperation with a start-up, and (3) developing a methodology to architecting systems concerning design for adaptability in the context of a European research project.

\subsubsection{Open Innovation planning methodology in family firms}

The research project aimed at developing a methodology to support companies in purposefully planning OI projects. Although the overall goal and general needs were similar, the three cooperating family firms (FFs) differ in certain aspects. The empirical insights concerning method design requirements are based on an explicit requirement analysis and an empirical observation of the FFs applying the methodology. The companies are indicated by "FF 1, FF 2 and FF 3" in the following section. The case studies were already published in Guertler (2016) but with a primary focus on the evaluation of the methodology instead of identifying general requirements of method design. The first FF was an automotive supplier of highly durable mechanical connecting parts. By using OI, it focused on identifying many new potential R\&D partners to develop a new alloy. The applied methods were of the groups of analysis, planning and evaluation/decision (cf. Section 3.1). From a primary partner search perspective, this case study allows insights in the design of data acquisition methods, operative description of method steps, and the adaptation and combination of methods. The second FF was a manufacturer of building technologies, which aimed at developing new solution ideas and concepts to solve a technical engineering problem by using OI. The applied methods were also of the groups of analysis, planning and evaluation/decision. From a more mechanical perspective, this case study also allows insights in the design of data acquisition methods, operative description of method steps, and the adaptation and combination of methods. The third FF was a producer of manufacturing plants and intended to develop a new product service system by using OI. Like the other FFs, the applied methods were of the groups of analysis, planning and evaluation/decision. This case study allows insights in method requirements in respect to organisational barriers and success factors, in addition to insights concerning data acquisition, method descriptions and adaptations of methods.

\subsubsection{Open Innovation planning methodology in a start-up}

The research project with the start-up also focussed on planning an OI project. The start-up was a spin-off of a larger parent company and comprised only three employees. The start-up focussed on developing a new product service system (PSS) in the context of shared economy. By using OI, it aimed at identifying further relevant OI partners to enhance the already existing PSS concept. The observation of the application of the planning methodology allowed insights in specific requirements of small companies, e.g. concerning limited investments in methods and strong focus on cost-benefit rations resulting from a limited manpower. In the following section, this company is indicated by "start-up".

\subsubsection{Design for adaptability methodology}

This European research project focused on developing a methodology to design products and systems concerning design for adaptability (DfA) (cf. www.amisa.eu). The project consortia comprised six companies of different sizes and countries. The methods within the superordinate methodology addressed the categories of analysis, planning and evaluation/decision (cf. Section 3.1). Along with the 
observation of method application, these companies were surveyed concerning requirements of the new methodology. These DfA-focused requirements were analysed concerning general requirements of method design. The derived insights focus on requirements concerning the methodology's integration into the organisational structures and processes of a company, e.g. acceptance by product developers. Requirements of the entire consortia are indicated by "Amisa", requirements of the automotive company by "MNE".

\subsection{Identification of requirements for designing methods and tools}

The analysis of explicitly stated requirements of the companies and the observation of method application in the companies revealed several requirements of method design. The framework in Section 3.3 support in structuring and deriving originally tacit requirements from the empirical insights. In this respect, the following guiding questions are used to reflect on all insights: How do the insights/findings affect the performance or cost-benefit ratio of a method? How do the insights/findings affect the comprehensibility and usability of a method? How do the insights/findings affect the applicability of a method? How do the insights/findings affect the inherent data collection of a method?

\subsubsection{Performance requirements}

Requirements of this category address the perceived performance of methods and their resulting cost-benefit ratio (Table 1). To ensure acceptance of employees such as product developers, it is crucial that a method clearly states its benefits as well as necessary efforts. It is also necessary to point out strengths and weaknesses as well as limitations of a method. This prevents wrong expectations of users which might result in disappointment and future refusal. To profoundly prove its benefits, methods should comprise performance measures, which can also be used for controlling issues. Concerning the effort and the risk of "over-engineering", it is necessary to review a method if it only comprises necessary functionalities. For larger methods, particularly small companies would appreciate an indication of potential benefits and short-term application cases of intermediate results. Another critical aspect from an industry perspective is the control of methods and inherent decision processes: along with transparent decision support, companies want to stay in control and make a decision themselves instead of leaving it to a method or tool. Thus, methods should focus on ranking alternative options rather than filtering.

Table 1. Performance requirements

\begin{tabular}{|c|c|c|c|}
\hline ID & Requirements & Description & Source \\
\hline \multicolumn{4}{|c|}{ General requirements } \\
\hline Per-1.1 & Consider cost-benefit ratio & $\begin{array}{l}\text { Required effort of method use needs to be compensated by a value gain (e.g. quality of } \\
\text { results, more robust results, reduced long-term costs); see Per-3.2. }\end{array}$ & MNE \\
\hline Per-1.2 & $\begin{array}{l}\text { Clearly state efforts and } \\
\text { benefits }\end{array}$ & $\begin{array}{l}\text { To ensure a sufficient understanding and purposeful use of a method, its benefits but } \\
\text { also its efforts and limitations should be clearly stated. }\end{array}$ & FF 1-3 \\
\hline Per-1.3 & Support decisions & $\begin{array}{l}\text { A method should support a profound decision making process but leave the final } \\
\text { decision and control to the users (e.g. ranking instead of filtering options). }\end{array}$ & $\begin{array}{l}\text { FF 1-3; } \\
\text { Amisa }\end{array}$ \\
\hline \multicolumn{4}{|c|}{ Application conditions } \\
\hline Per-2.1 & Indicate side effects & $\begin{array}{l}\text { Along with its primary purpose (e.g. problem analysis), a method should state additional } \\
\text { positive or negative effects (e.g. an improved homogenous knowledge level within a } \\
\text { project team). }\end{array}$ & start-up \\
\hline Per-2.2 & $\begin{array}{l}\text { State required timeframe for } \\
\text { method application }\end{array}$ & $\begin{array}{l}\text { A method should state the approximate timeframe of applying the method to allow } \\
\text { scheduling its application along with purposefully chosing bbetween different methods. }\end{array}$ & FF 1-3 \\
\hline \multicolumn{4}{|c|}{ Applicability in industry } \\
\hline Per-3.1 & $\begin{array}{l}\text { Allow performance } \\
\text { controlling }\end{array}$ & $\begin{array}{l}\text { A method should comprise specific KPIs, which indicate the performance of the method } \\
\text { and allow for controlling (e.g. number of generated ideas). }\end{array}$ & MNE \\
\hline Per-3.2 & Ensure pragmatism & $\begin{array}{l}\text { Save effort and avoid "over-engineering": find a balance between necessary details and } \\
\text { an appropriate level of pragmatism ("Pareto's 80:20 rule"); method should only comprise } \\
\text { required functionalities and point out aspects for tailoring. }\end{array}$ & FF 1-3 \\
\hline Per-3.3 & Provide interim results & $\begin{array}{l}\text { In the case of larger methods and methodologies: benefits and purpose of intermediate } \\
\text { results should be indicated if possible. This allows up-front wins, and increases the short- } \\
\text { term and overall benefits for method users and ensures their motivation. }\end{array}$ & start-up \\
\hline
\end{tabular}




\subsubsection{Presentation requirements}

This category comprises different aspects of understanding and learning a new method, along with aspects of usability (Table 2). To allow a profound selection of suitable methods, their purpose should be clearly stated. Since companies wish for an operative support, the method process should be described as step-by-step process and should indicate particularly relevant or critical elements. During the application of a method, companies like to have an overview of their current process status and progress. Closely linked to performance requirements, method profiles should be used to distinctively describe purpose, benefits and limitations as well as reasons to apply or not apply a method. Graphical process representations can further improve the comprehensibility of a method. Its usability can be enhanced by according templates and tools. In the context of workshop-based method applications, graphical or paper-based tools should be favoured. These visualise issues and support team discussions while software tools are better for subsequent analysis steps. Exemplary case studies and success stories can increase the understanding and motivation of companies to apply a method.

Table 2. Presentation requirements

\begin{tabular}{|c|c|c|c|}
\hline ID & Requirements & Des cription & Source \\
\hline \multicolumn{4}{|c|}{ General characteristics } \\
\hline Pre-1.1 & $\begin{array}{l}\text { Provide operational } \\
\text { support }\end{array}$ & $\begin{array}{l}\text { A method should provide a step-by-step process guidance that navigates particularly } \\
\text { inexperienced users through the method application process. }\end{array}$ & $\begin{array}{l}\text { FF 1-3; } \\
\text { start-up }\end{array}$ \\
\hline Pre-1.2 & $\begin{array}{l}\text { Clarify purpose of } \\
\text { method }\end{array}$ & $\begin{array}{l}\text { A method should clearly describe its purpose to allow a better understanding and } \\
\text { selection of methods (e.g. by linking a method to specific design/development process } \\
\text { phases, cf. Braun (2003)). }\end{array}$ & FF 1-3 \\
\hline Pre-1.3 & $\begin{array}{l}\text { Highlight relevant } \\
\text { elements }\end{array}$ & $\begin{array}{l}\text { Particularly relevant or critical steps and elements should be clearly indicated so users } \\
\text { can focus their attention onto them. }\end{array}$ & $\mathrm{FF} 2+3$ \\
\hline \multicolumn{4}{|c|}{ Process repres entation } \\
\hline Pre-2.1 & $\begin{array}{l}\text { Provide a process } \\
\text { overview }\end{array}$ & $\begin{array}{l}\text { Partiularly when a method/methodology comprises several (sub-) process steps, a } \\
\text { comprehensible overview of these process steps is crucial to allow a better } \\
\text { understanding. Optimally, the overview is structured in different layers of abstraction } \\
\text { (starting with a short summary, key steps, sub-steps, activities). Also see Pre-2.2. }\end{array}$ & $\begin{array}{l}\text { FF 1-3; } \\
\text { Amisa }\end{array}$ \\
\hline Pre-2.2 & \begin{tabular}{|l|} 
Provide a graphical \\
process representation
\end{tabular} & $\begin{array}{l}\text { Ideally, the method application should be illustrated as graphical process with destinctive } \\
\text { process steps and corresponding activities }\end{array}$ & FF 1-3 \\
\hline Pre-2.3 & $\begin{array}{l}\text { Allow tracking of } \\
\text { process status }\end{array}$ & $\begin{array}{l}\text { A method should allow tracking the current position in the process and the remaining } \\
\text { steps (process transparency), e.g. through using the process overview (cf. Pre-2.1). This } \\
\text { supports method controlling purposes. }\end{array}$ & $\begin{array}{l}\text { FF } 1+3 ; \\
\text { Amisa }\end{array}$ \\
\hline Pre-2.4 & Clarify required input & $\begin{array}{l}\text { A clear desription of required input (data, knowledge and resources) ensures a } \\
\text { successful application of a method. }\end{array}$ & MNE \\
\hline Pre-2.5 & Clarify expeted output & $\begin{array}{l}\text { A clear description of resulting output of a method (data, documents, knowledge, side } \\
\text { effects). }\end{array}$ & MNE \\
\hline \multicolumn{4}{|c|}{ Indus trial applicability } \\
\hline Pre-3.1 & Provide tool support & $\begin{array}{l}\text { To increase the method's applicability, according templates, tools and checklists should } \\
\text { be provided as well. }\end{array}$ & Amisa \\
\hline Pre-3.2 & $\begin{array}{l}\text { Provide application } \\
\text { case studies }\end{array}$ & $\begin{array}{l}\text { Exemplary application cases, particularly success stories, can increase the understanding } \\
\text { of the performance, limitations and application of a method. }\end{array}$ & FF 1-3 \\
\hline \multicolumn{4}{|c|}{ General us ability } \\
\hline Pre-4.1 & $\begin{array}{l}\text { State required user } \\
\text { experience }\end{array}$ & $\begin{array}{l}\text { Defining required preliminary knowledge or user experience (e.g. method beginners, } \\
\text { experienced users, experts) ensures that users are able to use a method and avoid } \\
\text { frustration due to being overwhelmed. }\end{array}$ & FF 1-3 \\
\hline Pre-4.2 & $\begin{array}{l}\text { Use comprehensive } \\
\text { language }\end{array}$ & $\begin{array}{l}\text { The use of daily language without or only limited number of special terms increases a } \\
\text { method's comprehensibility and reduces the risk of misunderstandings. }\end{array}$ & FF 1-3 \\
\hline Pre-4.3 & $\begin{array}{l}\text { Provide a } \\
\text { glossary of terms }\end{array}$ & $\begin{array}{l}\text { In the case of multiple necessary special terms, a glossary of terms should be included - } \\
\text { particularly when interdiciplinary method users are targeted. }\end{array}$ & FF 1-3 \\
\hline Pre-4.4 & $\begin{array}{l}\text { Ensure workshop } \\
\text { usability }\end{array}$ & $\begin{array}{l}\text { Paper-based method tools are more suitable for workshops as they visualise issues, } \\
\text { foster discussions and prevent users of getting lost in software functions. }\end{array}$ & $\begin{array}{l}\text { FF 1-3; } \\
\text { start-up }\end{array}$ \\
\hline
\end{tabular}

\subsubsection{Process requirements}

Process requirements address the implementation of methods into different organisational and process situations in companies (Table 3 ). Thus, a method should allow for tailoring, i.e. adapting 
its inherent process by adding or removing steps as well as for scaling the scope or intensity of single steps. To ensure its usability, a method should also indicate according points where adaptations and scaling is reasonable as well as potential interfaces to other methods or processes. If a method requires users from different departments of a company, these should be indicated. In this respect, discursive method elements ensure building a homogenous knowledge level within these interdisciplinary teams by explicating implicit knowledge. All (intermediate) method results and decision processes should be traceable and sufficiently documented to allow for retrospective reviews and lessons learnt.

Table 3. Process requirements

\begin{tabular}{|c|c|c|c|}
\hline ID & Requirements & Description & Source \\
\hline \multicolumn{4}{|c|}{ Situational application } \\
\hline Pro-1.1 & Ensure adaptability & $\begin{array}{l}\text { To allow tailoring to different use contexts, steps or elements of the method should be } \\
\text { able to be skipped, replaced or enhanced by alternative ones (e.g. through a modular } \\
\text { structure). }\end{array}$ & $\begin{array}{l}\text { FF 1-3; } \\
\text { Amisa }\end{array}$ \\
\hline Pro-1.2 & Ensure scalability & $\begin{array}{l}\text { To allow tailoring to different use contexts, the intensity of particular steps or elements } \\
\text { should be increasable or decreasable, e.g. the scope of an ideation method. }\end{array}$ & $\begin{array}{l}\text { FF 1-3; } \\
\text { Amisa }\end{array}$ \\
\hline Pro-1.3 & $\begin{array}{l}\text { Indicate tailoring } \\
\text { aspects }\end{array}$ & $\begin{array}{l}\text { To provide guidance when and how to tailor a method, it should indicate potential points } \\
\text { and aspects for adaptations and scaling to increase its usability. }\end{array}$ & FF 1-3 \\
\hline Pro-1.4 & $\begin{array}{l}\text { Indicate method } \\
\text { interfaces }\end{array}$ & $\begin{array}{l}\text { A method should indicate potential interfaces to other methods or general company } \\
\text { processes to ensure an efficient use of a method and data. }\end{array}$ & $\begin{array}{l}\text { Amisa; } \\
\text { start-up }\end{array}$ \\
\hline \multicolumn{4}{|c|}{ Situational process dependencies } \\
\hline Pro-2.1 & $\begin{array}{l}\text { Indicate contextual } \\
\text { influence factors }\end{array}$ & $\begin{array}{l}\text { A method should indicate relevant contextual influence factors (besides inputs), which } \\
\text { might influence the results or quality of results (e.g. specific room settings). }\end{array}$ & MNE \\
\hline Pro-2.2 & Consider dynamics & $\begin{array}{l}\text { If applied over a longer time, a method/methodology should sensitise for and support } \\
\text { users in recognising and managing dynamically changing inputs and context factors (e.g. } \\
\text { through reflective questions through the method's process). }\end{array}$ & $\begin{array}{l}\text { FF 1-3; } \\
\text { Amisa }\end{array}$ \\
\hline \multicolumn{4}{|c|}{ Process execution } \\
\hline Pro-3.1 & $\begin{array}{l}\text { Indicate ideal level } \\
\text { of detail }\end{array}$ & $\begin{array}{l}\text { A method shouls indicate the required level of details concerning input data and (interim) } \\
\text { results. }\end{array}$ & $\begin{array}{l}\text { MNE; } \\
\text { Amisa }\end{array}$ \\
\hline Pro-3.2 & $\begin{array}{l}\text { Allow department } \\
\text { spanning user teams }\end{array}$ & $\begin{array}{l}\text { Depending on the purpose of a method/methodology: it should support involving } \\
\text { different departments to create robust results (see also Pre-4.2, Pre-4.3, Pro-3.3). }\end{array}$ & MNE \\
\hline Pro-3.3 & $\begin{array}{l}\text { Indicate relevant } \\
\text { departments }\end{array}$ & $\begin{array}{l}\text { Interdisciplinary teams of method users can increase the quality of method results. Thus, } \\
\text { the method should indicate relevant departments and disciplines to support an effcient } \\
\text { selection. }\end{array}$ & FF 1-3 \\
\hline Pro-3.4 & $\begin{array}{l}\text { Include discursive } \\
\text { elements }\end{array}$ & $\begin{array}{l}\text { Purposeful discussions support the explication of implicit/tacit knowledge of different } \\
\text { method users and ensure a homogenous knowledge level within a team. }\end{array}$ & $\begin{array}{l}\text { FF 1-3; } \\
\text { start-up }\end{array}$ \\
\hline \multicolumn{4}{|c|}{ Process traceability and robus tness } \\
\hline Pro-4.1 & $\begin{array}{l}\text { Ensure traceability } \\
\text { of process and results }\end{array}$ & $\begin{array}{l}\text { (Intermediate) results and decisions should be continously documented to allow tracing } \\
\text { through the entire process of a method/methodology (e.g. through according } \\
\text { tools/templates and reminders during the method process). }\end{array}$ & FF 1-3 \\
\hline Pro-4.2 & $\begin{array}{l}\text { Support transparent } \\
\text { decisions }\end{array}$ & $\begin{array}{l}\text { If a method supports the decision between alternative options, it should indicate the } \\
\text { particular advantages and disadvantages of each option and support documenting the } \\
\text { reasons of a resulting decision. }\end{array}$ & $\begin{array}{l}\text { FF 1-3; } \\
\text { Amisa }\end{array}$ \\
\hline Pro-4.3 & Ensure reproducibility & $\begin{array}{l}\text { Test and ensure that identical input (data) and iterative application of a method lead to } \\
\text { similar/identical results. }\end{array}$ & MNE \\
\hline Pro-4.4 & Foster documentation & $\begin{array}{l}\text { Method should allow and specifically foster users to document (intermediate) results and } \\
\text { decisions for retrospective reviews and lessons learnt (also see Pro-4.1). }\end{array}$ & FF 1-3 \\
\hline
\end{tabular}

\subsubsection{Data collection requirements}

This category summarises requirements concerning the acquisition of data as input of a method (Table 4). This evinced as a critical aspect since insufficiently defined input criteria (e.g. in a survey) can result in insufficient results as well as unnecessarily high effort of data acquisition. Along with these procedural aspects of data acquisition, political and strategic company issues need to be considered which might bias input data. 
Table 4. Data collection requirements

\begin{tabular}{|c|c|c|c|}
\hline ID & Requirements & Des cription & Source \\
\hline \multicolumn{4}{|c|}{ Definition of as sess ment criteria as method input } \\
\hline In-1.1 & $\begin{array}{l}\text { Provide criteria } \\
\text { description }\end{array}$ & $\begin{array}{l}\text { A method should provide a clear description of each analys is criterion and its purpose, } \\
\text { i.e. contribution to the "big picture" of an activity/project. }\end{array}$ & FF 1-3 \\
\hline In-1.2 & Prvent ambiguity & $\begin{array}{l}\text { Criteria and method descriptions should avoid ambiguity; particulalrly in interdisciplinary } \\
\text { teams of method users, terms and expressions can have varying meanings (cf. Pre-4.3). }\end{array}$ & FF 1-3 \\
\hline In-1.3 & $\begin{array}{l}\text { Avoid time } \\
\text { independency }\end{array}$ & Criteria should be time independent (e.g. 'year of foundation' instead of 'age of company') & FF 1-3 \\
\hline In-1.4 & $\begin{array}{l}\text { Indicate multiple } \\
\text { options }\end{array}$ & $\begin{array}{l}\text { To avoid misunderstandings, a method should indicate whether single or multiple } \\
\text { options are expected (incl. a short notice of underlying reasons, to increase the } \\
\text { understanding of the users). }\end{array}$ & start-up \\
\hline In-1.5 & $\begin{array}{l}\text { Use destinctive } \\
\text { specification scales }\end{array}$ & $\begin{array}{l}\text { Destinctive specification scales reduces the effort of analysis/data collection through } \\
\text { preventing too rough as well as too precise levels of detail. }\end{array}$ & FF 1-3 \\
\hline In-1.6 & $\begin{array}{l}\text { Provide references for } \\
\text { scales }\end{array}$ & $\begin{array}{l}\text { Amgibuity and wrong assessments can be prevented through generally defined scale } \\
\text { specifications (e.g. what does "low, medium, high" mean for a specific criterion?). }\end{array}$ & FF 1-3 \\
\hline \multicolumn{4}{|c|}{ Ass ess ment of criteria as method input } \\
\hline In-2.1 & Limit as sessment effort & $\begin{array}{l}\text { Optimally, there are no more than } 30 \text { criteria, and/or an analys is duration of one day } \\
\text { maximum. Too many criteria can demotivate users and result in a boycott of the analysis. }\end{array}$ & FF 1-3 \\
\hline In-2.2 & State expected data & $\begin{array}{l}\text { To increase the usability, clear desription of required input data (quantitative vs. } \\
\text { qualitative), type of data, and level of detail; exemplary anwers can provide orientation to } \\
\text { the method users. }\end{array}$ & $\begin{array}{l}\text { MNE; } \\
\text { start-up }\end{array}$ \\
\hline In-2.3 & $\begin{array}{l}\text { State organis ational } \\
\text { and temporal focus }\end{array}$ & $\begin{array}{l}\text { A method should state the focus level of analysis, e.g. organisational (e.g. business unit } \\
\text { vs. entire company) and temporal (e.g. current status vs. average of last five years). }\end{array}$ & FF 1-3 \\
\hline In-2.4 & $\begin{array}{l}\text { Indicate potential data } \\
\text { source }\end{array}$ & $\begin{array}{l}\text { A method should state group/department that is likely to hold and be able to provide the } \\
\text { necessary information/data. }\end{array}$ & FF 1-3 \\
\hline In-2.5 & $\begin{array}{l}\text { Indicate links to } \\
\text { existing databases }\end{array}$ & $\begin{array}{l}\text { A method should be able to indicate and link to existing databases and process company- } \\
\text { spefically available data (to reduce application effort). }\end{array}$ & $\begin{array}{l}\mathrm{MNE} ; \mathrm{FF} \\
1-3\end{array}$ \\
\hline \multicolumn{4}{|c|}{ Potential barriers } \\
\hline In-3.1 & $\begin{array}{l}\text { Consider political } \\
\text { analysis barriers }\end{array}$ & $\begin{array}{l}\text { A method should indicate and support considering potential negative effects on internal } \\
\text { and external stakeholders, who - for instance - might feel offended by analys is results } \\
\text { (e.g. innovativeness of specific groups). }\end{array}$ & FF 1-3 \\
\hline In-3.2 & $\begin{array}{l}\text { Consider strategic } \\
\text { analys is barriers }\end{array}$ & $\begin{array}{l}\text { A method should indicate the potential strategic relevance and sensitivity of the analysis } \\
\text { results, which might cause rejection by industrial method users. }\end{array}$ & FF 1-3 \\
\hline
\end{tabular}

\section{Conclusion and outlook}

This paper proposes a research focus extension when exploring the application and diffusion of design and innovation methods in industry. While hitherto the focus has mainly been a "toolbox focus", i.e. on selection and implementation of methods, this research argues to add a "tool focus", i.e. on the methods themselves and their design. This paper presents an initial step in closing this gap.

Although design and innovation methods/methodologies provide different benefits to companies (Graner, 2013), their application in industry is still limited (Lindemann, 2016). Different authors have analysed potential reasons and according barriers from a method selection, method training and method implementation processes. Nevertheless, a detailed analysis of designing methods and tools themselves is still needed. The presented research focuses on closing this gap. It extracts and explicates implicit and scattered requirements for purposefully designing methods from literature, such as Albers and Schweinberger (2001), Braun (2005), Hutterer (2005) and Gericke et al. (2013). It details them and consolidates them with empirically identified requirements from industry case studies to an initial requirement list of methods design. In this respect, the method requirement framework allows a systematic derivation and structuring of requirements. The specific category of data collection stresses the importance of collecting sufficient data to achieve successful method outcomes. Concerning some requirements, the framework categories showed some overlap, which however should not limit the functionality of the framework. Interestingly, although the three analysed Open Innovation projects focused on different innovation problems, no differences of requirements concerning the designing of methods and tools could be identified. Future research needs to explore whether this is coincidence or due to specific factors, such as identical overarching topic (Open Innovation) or company characteristics (SMEs). 
This research contributes to academia through widening the research scope from selection and implementation of methods to designing the methods themselves. This supports building a holistic understanding of method application in industry as well as its enablers and barriers. The presented requirement framework helps to consolidate implicit and scattered requirements from literature and insights from empirical case studies. Other researchers can use the initial requirement list and according recommendations as checklist when developing new methods. This reduces the risk of typical greenhorn mistakes as well as improves the quality and applicability of methods. The resulting reduction of iterations of method enhancements allows to focus onto the actual method and its evaluation. The direct fulfilment of basic requirements can increase the acceptance by companies. The requirement list can also improve the researchers' understanding of company needs concerning the applicability of academic approaches and methods. Therefore, this paper also supports a systematic transfer of academic knowledge into industry in the long-run.

In the midterm, companies can benefit from a higher quality of design and innovation methods, which better meet their needs. Along with a reduced likeliness of "teething problems", methods can be better embedded in company processes and organisations. An increased usability of methods and situationspecific adaptability support the acceptance by product developers and other employees. Aspects like documentation and traceability of results and decisions increase the reliability of methods and support users in proving their work and outcomes. In the long-run, these aspects can lead to more systematic product development activities and more successful products.

A major limitation of this paper is its early stage of research resulting in a couple of other limitations that need to be addressed in future research. The first is the lack of completeness of requirements. The literature analysis revealed a highly scattered and interdisciplinary research field, which is characterised by an inconsistent use of terms and often only implicitly stated requirements, enablers and barriers of method design and application. A further literature analysis will be useful, which uses a broad variety of synonym terms and terms from other disciplines. Although the empirical analysis helped to concretise several requirements that had hitherto only been abstractly stated in literature, the level of abstraction of requirements is still not entirely consistent and needs to be homogenised. Another challenge is the context dependency and prioritisation of requirements. This includes a more detailed differentiation in general context-independent requirements of method design and specific requirements for different use cases, such as company and problem types. A prioritisation of requirements will allow to identify obligatory and optional method aspects, for instance through using a KANO prioritisation. This would help to focus efforts and resources on key aspects of method design. To address these issues, the number of cases has been limited so far and requires further and purposefully selected case studies in the future. In addition, the empirical analysis focused on method categories (cf. Section 3.1) of analysis, planning and evaluation/planning in the context of design projects. Future research also needs to address the remaining categories. Since the requirements were identified by a retrospective analysis and descriptive research design, their prescriptive validity needs to be evaluated in future industry or practice-based action research case studies. To allow a successful long-term application in companies, the designing of methods still needs to be closely linked to method selection and method implementation processes. This also includes a deeper consideration of the method users, such as method beginners vs. experts (cf. Braun, 2005).

In following research activities, the initial requirement list needs to be enhanced concerning additional requirements from other disciplines and application situations. This also includes a systematic differentiation in general and situation-specific requirements and a homogenisation of the level of abstraction of requirements. In addition, the requirement framework needs to be enhanced by procedural requirements of the method implementation process in terms of change management. The requirement framework can further be enlarged by a more detailed user perspective, such as methods beginners vs. experts, as well as small vs. large enterprises.

\section{References}

Albers, A. and Schweinberger, D. (2001), "Methodik in der praktischen Produktentwicklung - Herausforderung und Grenzen”, In: Spath, D. (Ed.), Vom Markt zum Produkt: Impulse für die Innovationen von morgen, LOGX-Verl., Stuttgart, pp. 1-9. 
Albers, A., Lohmeyer, Q. and Radimersky, A. (2012), "Individuelle und organisatorische Akzeptanz von Methoden des Systems Engineering", Tag des Systems Engineering Systems Engineering Konferenz, Padeborn, Germany, November 07 - 09, 2012.

Albers, A., Reiß, N., Bursac, N., Urbanec, J. and Lüdcke, R. (2014), "Situation-appropriate method selection in product development process - empirical study of method application", NordDesign 2014, Espoo, Finland / Melbourne, Australia, August 27 - 29, 2014.

Badke-Schaub, P., Jaap, D. and Roozenburg, N. (2011), “Towards a Designer-Centred Methodology: Descriptive Considerations and Prescriptive Reflections", In: Birkhofer, H. (Ed.), The future of design methodology, Springer, London, pp. 181-197. https://doi.org/10.1007/978-0-85729-615-3_16.

Bavendiek, A.-K., Inkermann, D. and Vietor, T. (2016), "Teaching design methods with the interactive 'Methodos' portal", Proceedings of the DESIGN 2016 / 14th International Design Conference, Dubrovnik, Croatia, May $16-19,2014$, The Design Society, Glasgow.

Birkhofer, H., Kloberdanz, H., Berger, B. and Sauer, T. (2002), "Cleaning up design methods - Describing methods completely and standardised", Proceedings of the DESIGN 2002 / 7th International Design Conference, Dubrovnik, Croatia, The Design Society, Glasgow.

Braun, T. and Lindemann, U. (2003), "Supporting the selection, adaption and application of methods in product development", Proceedings of the 14th International Conference on Engineering Design (ICED 03), Stockholm, Sweden, August 19-21, 2003, The Design Society, Glasgow.

Braun, T.E. (2005), Methodische Unterstützung der strategischen Produktplanung in einem mittelständisch geprägten Umfeld, $\mathrm{PhD}$ thesis, Tehnical University of Munich.

Eckert, C.M. and Clarkson, J. (2005), "Design Process Improvement A review of current practice”, In: Clarkson, J. and Eckert, C.M. (Eds.), Design process improvement: A review of current practice, Springer, London, pp. $1-29$.

Ehrlenspiel, K. and Meerkamm, H. (2013), Integrierte Produktentwicklung: Denkabläufe, Methodeneinsatz, Zusammenarbeit, Carl Hanser, Munich, Germany.

Feller, J., Parhankangas, A., Smeds, R. and Jaatinen, M. (2013), "How Companies Learn to Collaborate. Emergence of Improved Inter-Organizational Processes in R\&D Alliances”, Organization Studies, Vol. 34 No. 3, pp. 313-343. https://doi.org/10.1177/0170840612464758

Gericke, K., Eckert, C.M. and Stacey, M. (2017), "What do we need to say about a design method?", Proceedings of the 21st International Conference on Engineering Design (ICED 17), Vancouver, Canada, August 21 - 25, 2017, The Design Society, Glasgow.

Gericke, K., Kramer, J. and Roschuni, C. (2016), “An Exploratory Study of the Discovery and Selection of Design Methods in Practice", Journal of Mechanical Design, Vol.138 No.10, pp. 1-10. https://doi.org/10.1115/1.4034088

Gericke, K., Meißner, M. and Paetzold, K. (2013), "Understanding the Context of Product Development", Proceedings of the 19th International Conference on Engineering Design (ICED 13), Seoul, Korea, August 19 - 22, 2013, The Design Society, Glasgow.

Grabowski, H. and Geiger, K. (1997), Neue Wege zur Produktentwicklung, Raabe-Innovationen, Raabe, Stuttgart, Wien u.a.

Graner, M. (2013), Der Einsatz von Methoden in Produktentwicklungsprojekten: Eine empirische Untersuchung der Rahmenbedingungen und Auswirkungen, Springer Gabler, Wiesbaden.

Gronum, S., Verreynne, M.-L. and Kastelle, T. (2012), "The role of networks in small and medium-sized enterprise innovation and firm performance", Journal of Small Business Management, Vol. 50 No. 2, pp. $257-282$. https://doi.org/10.1111/j.1540-627X.2012.00353.x

Guertler, M.R. (2016), Situational Open Innovation - Enabling Boundary-Spanning Collaboration in Small and Medium-sized Enterprises, PhD thesis, Technical University of Munich.

Guertler, M.R., Michailidou, I. and Lindemann, U. (2016), "How to assess a company's Open Innovation situation?", Design Science, Vol. 2, pp. 1-30. https://doi.org/10.1017/dsj.2016.4

Hutterer, P. (2005), Reflexive Dialoge und Denkbausteine für die methodische Produktentwicklung, PhD thesis, Technical University of Munich.

Kirschner, R.J. (2012), Methodische offene Produktentwicklung, PhD thesis, Technical University of Munich.

Lindemann, U. (2009), Methodische Entwicklung technischer Produkte: Methoden flexibel und situationsgerecht anwenden, VDI-Buch, Springer, Berlin.

Lindemann, U. (2016), "Methoden in der Produktentwicklung", In: Lindemann, U. (Ed.), Handbuch Produktentwicklung, Carl Hanser, Munich, pp. 623-628. https://doi.org/10.3139/9783446445819.021

Lopez-Mesa, B., Eriksson, S. and Thompson, G. (2004), "The decomposition and linkage of design methods and problems”, 6th Design Structure Matrices (DSM) International Workshop, Cambridge, UK, September 12 14, 2004. 
Pahl, G., Beitz, W., Blessing, L., Feldhusen, J., Grote, K.-H. and Wallace, K. (2007), Engineering Design - A systematic approach, 3rd ed., Springer, London.

Tomiyama, T., Gu, P., Jin, Y., Lutters, D., Kind, C. and Kimura, F. (2009), "Design methodologies. Industrial and educational applications”, CIRP Annals - Manufacturing Technology, Vol. 58 No.2, pp. 543-565. https://doi.org/10.1016/j.cirp.2009.09.003

Ulrich, K.T. and Eppinger, S.D. (2008), Product design and development, 4th ed., McGraw-Hill Higher Education, Boston, MA, USA.

Dr.-Ing. Matthias R. Guertler, Postdoctoral Research Fellow

University of Technology Sydney, Design Innovation Research Centre

PO Box 123 Broadway, 2007 Broadway, Australia

Email: matthias.guertler@uts.edu.au 